\title{
Silurian metalliferous nodules from the region of Asaritsa peak, West Balkan mountain - preliminary results
}

\section{Силурски металоносни конкреции от района на вр. Асарица, Западна Стара планина - предварителни резултати}

\author{
Atanas Hikov $^{1}$, Valeri Sachanski, ${ }^{1,2}$ Zlatka Milakovska ${ }^{1}$, Elitsa Stefanova ${ }^{1}$, Irena Peytcheva', \\ Silvia Chavdarova ${ }^{1}$, Milen Stavrev ${ }^{I}$ \\ Атанас Хиков ${ }^{1}$, Валери Сачански ${ }^{1,2}$, Златка Милаковска ${ }^{1}$, Елица Стефанова ${ }^{1}$, Ирена Пейчева ${ }^{1}$, \\ Сильия Чавдарова ${ }^{1}$ Милен Ставрев ${ }^{1}$
}

${ }^{1}$ Geological Institute, Bulgarian Academy of Sciences, Acad. G. Bonchev Str., Bl. 24, 1113 Sofia; E-mail: ahikov@geology.bas.bg
${ }^{2}$ University of Mining and Geology, Studentski Grad, Prof. Boyan Kamenov Str., 1700 Sofia; Email: v_sachanski@geology.bas.bg

Keywords: Silurian, metalliferous nodules and sediments, geochemistry, manganese, REE, West Balkan.

\section{Introduction}

The high growth of world economy led to the depletion of traditional resources and increased demand for rare-earth (REE) and other critical elements. The interest towards deep-sea nodules has risen after research studies determined them as a potential source for high-tech elements from the REE group, especially heavy REEs, Y and Sc (Kato et al., 2011; Hein et al., 2013). Bulgaria participates in nodule research in the Clarion-Clipperton Zone (CCZ), North Pacific Ocean as a member state of the Joint Organization Interoceanmetal and the first data about REE and $\mathrm{Y}$ distribution in modern nodules from $\mathrm{CCZ}$ were reported by Dimitrova et al. (2014). Further, on our attention is focused on looking for metalliferous nodules and sediments in other geological environments, in order to describe their occurrence and distribution and test whether they contain REE and critical elements. This study presents the first data for polymetallic nodules and host sediments in Silurian sequence from the region of Asaritsa peak, West Balkan mountain. A complex of field work, microscopic and laboratory technics (such as XRD, ICP-OES, SEM, LA-ICP-MS of whole rock fused pellets and minerals) are used to characterize the mineralogy, petrology and geochemistry of polymetallic nodules and host sediments.

\section{Geological setting}

The study area is a part of the Svoge Unit (Dabovski, Zagorchev, 2009) which is the northernmost fragment of the Srednogorie Zone and is thrust to the north over the West Balkan Unit. The pre-Mesozoic basement of the unit is a Palaeozoic, mainly shale succession that is topped by Upper Devonian to lowermost Carboniferous flysch. This sequence is a part of the Palaeozoic Balkan Terrane (Yanev, 2000). The Llandoverian sedimentological succession is built up mostly of thin-bedded, dark grey to black cherts (lydites), organic-rich shales, and siliceous shales of the Saltar Formation (Sachanski, Tenchov, 1993). The chronostratigraphical range of the chert-shale succession has been determined to span the upper Hirnantian Stage of the Upper Ordovician Series to the lower Telychian Stage of the Llandovery Series, based on graptolites (Sachanski, 2017, and references therein). In the middle of this sequence, Sachanski reported one undisturbed section, situated at $\sim 800 \mathrm{~m}$ to the SW of Asaritsa Peak, which includes the upper part of the Aeronian and the lowermost part of the Telychian (Llandovery Series). The section also contains a 6-m thick interval of graptolite-barren pale-coloured shale. It has been recognized as a parastratotype for the middle part of the Saltar Formation.

The Asaritsa section studied (Fig. 1A) is exposed in the roadcut of a small forest road SW of Yablanitsa Village, about $800 \mathrm{~m}$ WSW of Asaritsa Peak. The section begins with $\sim 20 \mathrm{~cm}$ of thin-bedded $(3-5 \mathrm{~cm})$, black siliceous shales, separated by similar but inclinally folded sediments by normal fault. These sediments yielded graptolite taxa that could be attributed to the convolutus Zone. The section continues upwards with a $1.3 \mathrm{~m}$ thick interval of very thin beds $(1-3 \mathrm{~cm})$ and thick laminae $(3-10 \mathrm{~mm})$ of black shale. The uppermost part of these black shales is attributed to the upper part of the sedgwickii Zone - uppermost Aeronian. Upwards the succeeding level is represented by a $\sim 6.5 \mathrm{~m}$ thick graptolite-barren pale shale. Several levels with nodules occur within the pale shale interval, as the 
first one, situated $40 \mathrm{~cm}$ above the base of the package, is markedly well sustained, $20 \mathrm{~cm}$ in thickness (Fig. 1B). Up-section, a $\sim 1 \mathrm{~m}$ thick packet crops out, comprising very thin-bedded $(1-3 \mathrm{~cm})$, dark grey to grey siliceous shales. This packet is covered by $\sim 1 \mathrm{~m}$ thick to thin laminae $(1-10 \mathrm{~mm})$ of dark grey to black shales. Parapetalolithus palmeus and Spirograptus guerichi are documented at the base of the latter, being characteristic for the guerichi Zone - lower Telychian (Sachanski, 2017).

\section{Nodules and host sediment characteristics}

The microscopic features of the nodule hosting sediments determine them as clast-poor silty mudstone to cherty mudstone. The randomly dispersed silty component is in variable amount (negligible to 10 $30 \%$ ), mainly of quartz and muscovite, and rarely - of rock clasts. A muddy-cherty component forms a groundmass characterized by a homogeneous texture and consists of low birefringent clay particles and quartz grains of low crystallinity. The rocks are laminated as the primary structures are well defined on the muscovite flakes orientation. Secondary processes are marked by siderite as rhombohedral sparry crystals and clusters of microcrystals disseminated in the mudstones.

Polymetallic nodules crop-out in several levels of the Asaritsa section. The best represented nod- ules in the first level (Fig. 1B) are the largest size $(12 \times 8 \times 5 \mathrm{~cm})$, as their long axis is transverse to the layer. There are also smaller nodules with elliptical to spherical shape and diameter from 2 to $6 \mathrm{~cm}$. Two nodule types are observed. More common are nodules with a hard core of quartz with evenly disseminated carbonate mineral $(\sim 20 \%)$ and pyrite $(\sim 1 \%)$. The carbonate mineral is rhombohedral and zonal with varying composition from Mn-containing ankerite and siderite to Fe-containing rhodochrosite. A transitional zone begins towards the periphery of the nodule cores where alteration of carbonate to transitional phases is observed. In the outer zone the carbonate mineral is replaced by goethite and $\mathrm{Mn}-\mathrm{Fe}$ oxyhydroxides with variable composition, which build separate zones preserving the zonation of the carbonate minerals. Pyrite is partly or completely replaced by goethite. The nodule shells are black and built of several thin layers often separated by empty space. Layers are built of quartz, chlorite, sericite, goethite, $\mathrm{Mn}-\mathrm{Fe}$ oxyhydroxides and siderite in variable proportions. The nodules of the second type are less common. They are smaller and have pale cores with irregular form. The composition is mainly of quartz, muscovite \pm chlorite. The shells are black and are identical in composition and texture with the shells of the first type nodules.

Generally, the sedimentary rocks have a relatively homogeneous chemical composition. The $\mathrm{MnO}$ con-

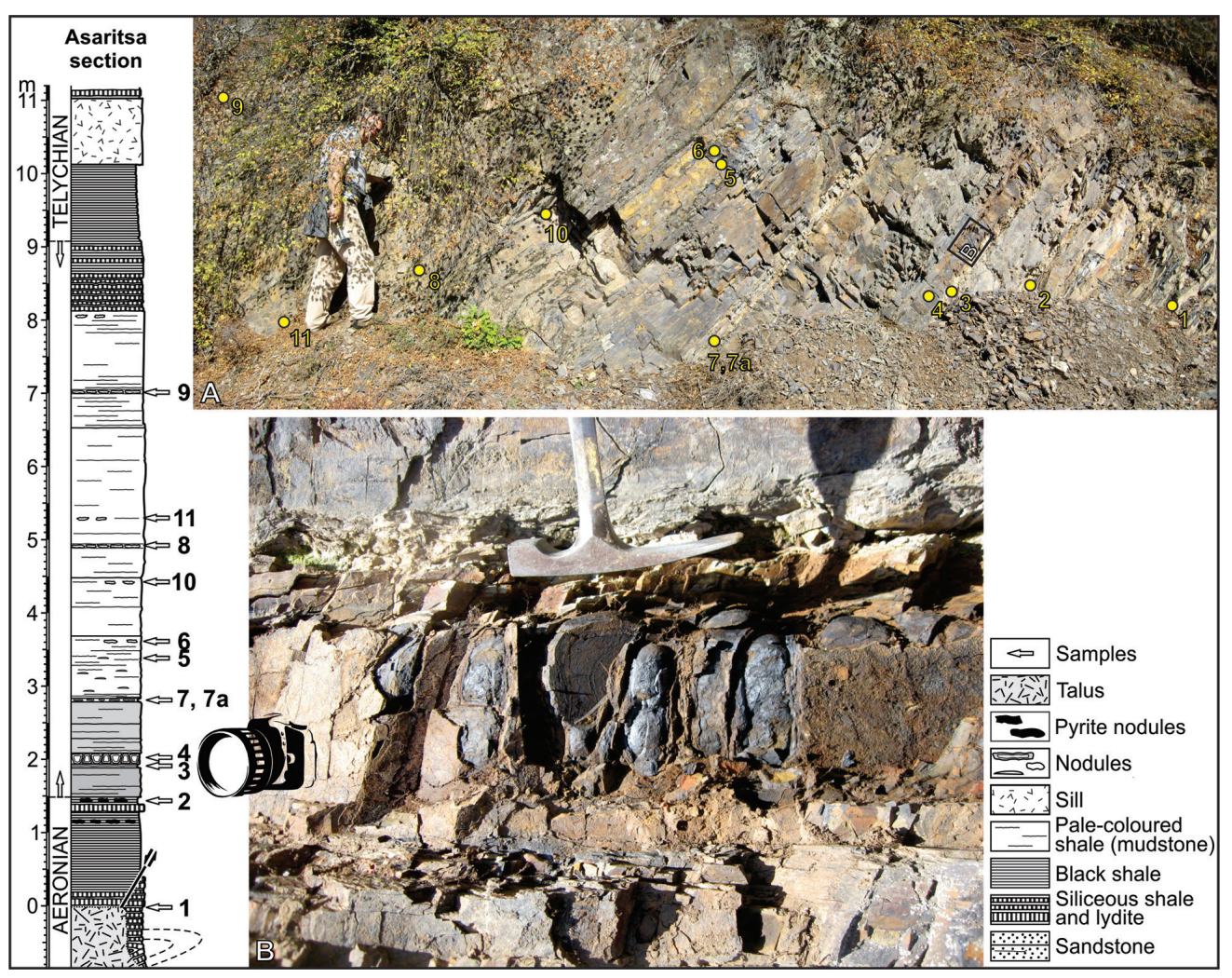

Fig. 1. Lithostratigraphic column of Asaritsa section (after Sachanski, 2017) and field photographs: $A$, Asaritsa section; $B$, first nodule level (sample 4) 
tent is low and the $\mathrm{Fe}_{2} \mathrm{O}_{3}$ varies between 0.55 and $11.56 \%$. Relatively high is the content (in ppm) of the following elements: V (100.6-355.2), Ni (25.1171.2), $\mathrm{Cu}(14.7-615.0), \mathrm{Y}(36.4-45.9), \mathrm{REE}(\mathrm{REE}$ 162.7-296.8) and EREEY (199.1-340.2), while $\mathrm{Cr}$ (83.5-111.4) is lower compared to NASC.

Two types of nodule cores are distinguished based on their Fe and Mn content: i) cores with high $\mathrm{Fe}_{2} \mathrm{O}_{3}(14-18 \%)$ and $\mathrm{MnO}(\sim 5.5 \%)$ content that are enriched in $\mathrm{Co}$ and $\mathrm{Ni}$ and poor in $\mathrm{Cu}$; ii) cores with low $\mathrm{Fe}_{2} \mathrm{O}_{3}(1.6-3.3 \%), \mathrm{MnO}(0.20-0.25 \%)$, Co and $\mathrm{Ni}$ and slightly high $\mathrm{Cu}$. The nodule shells show high $\mathrm{Fe}_{2} \mathrm{O}_{3}$ (average 17.87\%) and $\mathrm{MnO}$ (average 5.16\%) content, and are enriched in Co (22.5-51.7 ppm) and $\mathrm{Ni}$ (104.2-194.4 ppm). Copper content is elevated in separate samples only up to $150 \mathrm{ppm}$. In the cores and in the shales, the EREEY vary between 116 and $250 \mathrm{ppm}$ and their distribution does not show any regularities. Chondrite-normalized REE patterns of all samples show well expressed positive Ce $\left(\mathrm{Ce}^{*}=1.07-1.54\right)$ and negative $\mathrm{Eu}\left(\mathrm{Eu}^{*}=0.56-0.74\right)$ anomaly. Compared to NASC, the sedimentary rocks are enriched in all REE, only one sample has REE content close to the NASC. The nodule cores are depleted in REE compared to the NASC, while the shells are close to or depleted in the LREE and HREE, and enriched in MREE.

LA-ICP-MS study of nodule minerals shows that pyrite contains significant concentrations (in ppm) of Mn (89.5-1639), Co (296-3058), Ni (1219-16477), $\mathrm{Cu}$ (217-5737), As (913-2776), Se $(<103-247)$, $\mathrm{Sb}$ (9-813), Te (18.3-27.3), $\mathrm{Pb}(73.4-4028)$ and Bi (1.35-175). Goethite which forms after pyrite is also enriched of some of those elements: Mn (677110944), Co (413-782), Ni (689-714), Cu (547-902), As (1239-1467), Sb (34.7-38.4), Pb (212.4-215.8), Bi (29.4-57.2). The second goethite type which deposited in the nodule shells contains Mn (7122-13038), Cr (244-536), Zn (107-144), less Co (6.8-10.5), Ni (55.5-97.3) and also Y(10.4-16.1), La (8.8-12.2), Ce (37-44), Pr (2.8-3.8) and Nd (11.8-15.4). Carbonate minerals are poor in impurities, having very low content of $\mathrm{Rb}$ (up to 7.5), $\mathrm{Sr}$ (13.4-48.3), Y (2.2-28.5), Ba (31.6-95.8) and LREE (La 2.1-7.1, Ce 2.3-11.9, Pr $1.2-2.1$, Nd up to 17). Fe-Mn oxyhydroxides which form mostly after carbonate minerals contain traces of Co (22-289), Ni (63.7-231), Zn (56,6-283), Y (11.755), La (12.2-38.5), Ce (16.9-102.5), Pr (0.96-11.1), Nd (21-52.5), sometimes Ga (up to 42), Sm (up to 33.6) and Dy (up to 16.8). The matrix (mainly quartz, sericite \pm chlorite) is rich of Mn (9622-46517) and $\mathrm{Fe}(41461-107394)$ and contains also Ti (983-5512), $\mathrm{Ga}(8.4-15), \mathrm{Rb}$ (24.7-62.4), Zr (27.3-66.6), Nb (2.6-12.5), Ba (346-774) and LREE (La 5.7-21, Ce 5.6-26.2, Pr 0.96-2.3, Nd 6.9-13.1).

\section{Discussion and conclusions}

The geochemical study of the Silurian nodules reveals their polystage formation. The structural and textural characteristics of the host sediments imply deposition from debris to mudflow in distal shelf (Sachanski, Tenchov, 1993; Yanev, 2000) in a normal to oxidizing environment. The formation of the nodules with high $\mathrm{Fe}$ and $\mathrm{Mn}$ content is related to diagenetic processes and synchronous/postponed siderite formation. We suggest the siderite formation under reducing, waterlogged, conditions characterised by low to negative Eh (redox) values and high pH values (Krauskopf, 1979) as well as higher concentration of ferrous iron. In this environment, sulphate is exhausted, and iron carbonate (siderite) is preferentially precipitated. The alteration processes continue with siderite rhombohedra attacked by $\mathrm{Fe}-\mathrm{Mn}$ oxyhydroxides that are also filling fractures and pores in the sediments and nodules.

The described Silurian nodules and sediments show a number of similarities with modern deepsea environments of polymetallic nodule bearing sediments. The modern deep-sea nodules are also enriched in $\mathrm{Fe}$ and $\mathrm{Mn}$, as well as $\mathrm{Co}, \mathrm{Ni}, \mathrm{Cu}$ and REEY (Hein et al., 2013; Dimitrova et al., 2014) and suggest again that during the geological periods of the Earth's evolution, similar processes of accumulation of these elements during the sedimentation on the ocean floor take place. Some differences such as probable depth of deposition, mechanism of nodule formation, degree of lithification are also established.

Acknowledgements: The study is financially supported by Bulgarian National Science Fund, project КП-06-H34/6.

\section{References}

Dabovski, H., I. Zagorchev. 2009. Introduction: Mesozoic evolution and Alpine structure. Alpine structure. - In: Zagorchev, I., H. Dabovski, T. Nikolov (Eds), Geology of Bulgaria. Vol. II. Mesozoic Geology. Sofia, "Prof. M. Drinov" Academic Press, 30-37 (in Bulgarian, with English abstract).

Dimitrova, D., Z. Milakovska, I. Peytcheva, E. Stefanova, V. Stoyanova, T. Abramowski, M. Wälle. 2014. Trace element and REY composition of polymetallic nodules from the Eastern Clarion-Clipperton zone (Northern Pacific Ocean) determined by in situ LA-ICP-MS analyses. - C. R. Acad. bulg. Sci., 67, 2, 267-274.

Hein, J., K. Mitzell, A. Koschinsky, T. Conrad. 2013. Deep-ocean mineral deposits as a source of critical metals for high- and green-technology applications: Comparison with land-based resources. - Ore Geology Reviews, 51, 1-14.

Kato, Y., F. Fujinaga, K. Nakamura, Y. Takaya, K. Kitamura, J. Ohta, R. Toda, T. Nakashima, H. Iwamori. 2011. Deep-sea mud in the Pacific Ocean as a potential resource for rare-earth elements. - Nature Geoscience, 4, 535-539.

Krauskopf, K. B. 1979. Introduction to Geochemistry. New York, McGraw-Hill, 617 p.

Sachanski, V. 2017. The Silurian stage boundaries in Bulgaria: the challenge of the Aeronian/Telychian (Llandovery) boundary. Geologica Balc., 46, 2, 3-10.

Sachanski, V., Y. Tenchov. 1993. Lithostratigraphical subdivision of the Silurian deposits in the Svoge anticline. - Rev. Bulg. Geol. Soc., 54, 1, 71-81 (in Bulgarian, with English abstract).

Yanev, S. 2000. Palaeozoic terranes of the Balkan Peninsula in the framework of Pangea assembly. - Palaeogeography, Palaeoclimatology, Palaeoecology, 161, 1-2, 151-177. 